\title{
The Phenomenon of Online Shopping in the Millennial Generation
}

\author{
Selvi Esther Suwu \\ selvi.suwu@uph.edu \\ Economic Education, University of Pelita Harapan
}

\begin{abstract}
The digital age influences the lifestyle of millennials in daily life, where the internet and gadgets are necessary things. This can be seen from communicating with others until buying things on the internet. The objective of this research is to see the phenomenon that is happening in a millennial generation through the phenomenon of online shopping. In line with this, the marketing mix also developed into 7P which are Product, Price, Place, Promotion, Physical Evidence, People, Process. The connection with this research is to look at the marketing mix with the millennial generation in their online shopping behavior. The respondents of this study were UPH students, the questionnaire as a research instrument, and the data were processed and analyzed descriptively. The results obtained: the phenomenon of online shopping in the millennial generation likes online shopping because it is practical, cheaper prices, variants/types of complete products, products purchased according to expectations, saving time and easy to do. Types of products purchased: clothing, cosmetics, and electronics, services: transportation tickets. first-order product from 7P, second price, third promotion factor followed by distribution, process, people and physical facilities.
\end{abstract}

Keywords: Online shopping, the millennial generation, phenomenon

\section{Introduction}

Millennial era is a designation that reflects the current situation, while millennial generation according to Kotler, Armstrong, Ang, et al, in their book An Asian Perspective's principle of marketing is "The Millennials are their utilities fluency and comfort with computer, digital, and internet technology" [1]. At this point, it is necessary to see what is important in adolescent activities in their daily lives. Starting from waking up by looking at a cellphone, going to school or college using public transportation such as ordering an online taxi, breakfast and lunch by ordering food using the application on a mobile phone, then chatting, watching favorite shows, looking for the latest news to just look around ( browsing) on a cellphone or laptop. Living with gadget facilities along with the conveniences of online services makes millennial generation often referred to as instant generation. Technology advancement brings Millenials can do activities faster and effectively regardless of space and time.. The modern lifestyle that has become a daily life of millennial generation is supported by the Indonesian by providing a digitalization for public service (DILAN or Digital Melayani [2]. The government understands that the needs of the community will now be more easily fulfilled if the state starts to do digitalization to provide optimal services. This greatly impacts the economic sector such as changes in purchasing behavior in society.. Nowadays, sellers and traders are using internet as a medium for selling is a form of breakthrough that can eliminate time and space constraints. Consumers can buy anytime and from anywhere, even from 
abroad. 20th century is the beginning era of digital marketing [3]. The development of online business makes writers interested in researching about the phenomena that occur in the millennial generation as consumers of online shopping. Researchers see changes in consumer purchasing behavior This can be associated with 7 marketing mix, namely product, price, promotion, place (distribution), people, process and physical evidence.

The millennial generation in this study are UPH students who shop online within the age level of 18-19 years old that can be said to be millennial generation. Millennials can be said that they have known digitalization since they were young. Kotler in his book Marketing 4.0 says that teenagers are potential consumers who are adaptable and are not afraid to try new products or services. Currently, new and developing services are through online services such as transportation (motorbike, car), food purchases, delivery of goods as well as financial payment technology [4]. This means that the development of digitalization is growing not only on social media but also extending to sales, which is online shopping.

The research objective is to see the phenomenon that is happening in millennial generation related to online shopping.

\section{Literature Review}

Online shopping in here means the same as digital marketing according to Elliot [5]"refers to all of the activities involved in planning and implementing marketing in the electronic environment, including the internet and web on computers, tablets, and smartphones, and other information and telecommunications technologies". All products/services can be offered on the internet and consumers can easily search and find what suits their needs.

Millennial generation is born between 1977 and 2000 [1]. This generation is interesting to conduct research for further study because it has a different living environment than $\mathrm{X}$ Generation, which is the rapid development of technology in the millennial generation.

Rundle, Thiele, and Waller wrote in his book Marketing third Editon Marketing mix (7P) [5]: Product, Price, Place, Promotion, Physical Evidence, People, Process.

1. Product $=$ A goods, service or idea to the market for exchange.

2. Price $=$ is the amount of money a business demands in exchange for its offerings

3. Promotion $=$ the marketing activities that make potential customers, partners and society aware of and attracted to the business's offerings.

4. Distribution (or place) $=$ the means of making the offer available to the customer at the right time and place.

5. People $=$ refers to any person coming into contact with customers who can affect the value for customers.

6.Process $=$ the systems used to create, communicate, deliver and exchange an offering.

7. Physical evidence $=$ tangible cues that can be used as a means to evaluate service quality prior to purchase.

Marketing mix develops from $4 p$ to $7 \mathrm{P}$, companies must be more sensitive to the market. The development of 4P to 7P also affects consumer behavior, the definition of Consumer Behavior according to Sangadji and Sopiah [6] : Individual or group behavior from feeling the desires or and needs of the product / service then acting to fulfill that desire / need until finally feeling satisfied or not towards the product / service. The needs and desires of each consumer 
are different, many factors affect consumers, but the most important is the end result after using goods / services consumers are satisfied. Consumer satisfaction becomes a value for the company.

Another definition of consumer behavior according to Supranto and Limakrisna " merupakan interaksi dinamis antara kognisi, afeksi, perilaku, dan lingkungannya di mana manusia melakukan kegiatan pertukaran dalam hidup mereka" [7].

\section{Research Methodology}

This research generally discusses about the phenomenon of millennial generation in online shopping. According to Iskandar, [8] phenomenon research is a descriptive study which is to make a percentage of the calculation of the number of respondents then the results are translated and linked to relevant theories.

It is clear that the subject of this study is the millennial generation, the researchers taking the sample are UPH students. Based on the Iskandar Purposive Sampling "Pengambilan sampel berdasarkan penilaian subjek peneliti berdasarkan pada karakteristik tertentu yang dianggap mempunyai sangkut paut dengan karakteristik populasi yang sudah diketahui sebelumnya dengan pertimbangan tertentu." [8]

Place, Time and Subject of Research

This research was conducted at UPH Tangerang, with 33 responden from UPH students and the time of research in May 2019.

The instrument used was a questionnaire, before the questionnaire was distributed the questionnaire was validated first. Validation is done by discussing the contents of the questionnaire with experts, then the questionnaire is made and arranged.

\section{Results and Discussion}

Table 1. Respondents' opinions regarding online shopping

\begin{tabular}{|c|c|}
\hline Like Online Shopping & Don't Like online shopping \\
\hline 32 & 6 \\
\hline The reason & The reason \\
\hline - $\quad$ Practical, Cheaper price & - $\quad$ Not necessarily safe/long to arrive \\
\hline Complete product variant & - $\quad$ Items are different from \\
\hline According to the expectation & expectations \\
\hline Don't waste a lot of time and energy & - $\quad$ There is a shipping cost \\
\hline Fast, easy/simple & \\
\hline
\end{tabular}


The millennial generation in table 1 expressed their opinion that they like online shopping as many as 32 people $32 / 38 \times 100 \%=84 \%$ the reason is practical online shopping, cheaper prices, variants/types of complete products, products purchased in accordance with expectations, saving time, quickly until to consumers and online shopping is also easy to do. Indeed online shopping is beneficial for consumers, "Convenience"[9] according to Alma, explaining convenience such as anytime shopping, no need to leave the house. The millennial generation is easy to adapt to the internet.

Table 2. How to shop online

\begin{tabular}{lllc}
\hline Easy/simple & Ordinary & Difficult & Very difficult \\
\hline 28 & 4 & 1 & - \\
\hline
\end{tabular}

Table 2 shows Respondents in responding to the question of how to shop online 28 / $33 \mathrm{X} 100 \%=84 \%$ said it was easy, $4 / 33 \mathrm{X} 100 \%=12 \%$ of ordinary respondents

Table 3. Types of Products purchased online

\begin{tabular}{lrlr}
\hline Food & 8 & Electronic & 10 \\
Beverage & 1 & & \\
Clothes & 23 & Beauty product & 11 \\
Shoes & 6 & Household equipment & 9 \\
School/work supplies & 4 & Others & 4 \\
\hline
\end{tabular}

This table 3 the most types of products purchased online are clothing, as many as 23/76 X $100 \%=30 \%$, the second most are beauty products $11 / 76 \mathrm{X} 100 \%=14 \%$, differing slightly from beauty products, the third-largest electronics with $10 / 76 \mathrm{X} 100 \%=13 \%$ other supplies and food are also quite a lot who buy online. This is in accordance with the characteristics of the millennial generation which is currently still at the stage of meeting its clothing needs with the type of products purchased online is clothing, the second most are beauty products and then the third is electronics.

Table 4. Types of Services purchased online

\begin{tabular}{lc}
\hline Travel Tickets (Plane, Train, etc.) & 26 \\
\hline Rent Lodging & 11 \\
No answer & 2 \\
\hline
\end{tabular}


In addition to products that are frequently purchased in table 4, services can also be purchased online, as many as 26 respondents buy travel tickets (planes, trains, etc.). $26 / 39 \mathrm{X} 100 \%=$ $67 \%$, while respondents who use online to buy rental services as many as 11 respondent: $11 /$ $39 \mathrm{X} 100 \%=28 \%$. Respondents are more likely to buy the type of travel ticket service because transportation is more generally needed than rental accommodation. Respondents are millennials, ages range start from 18-19 years, which every day require public online transportation rather than lodging rentals.

Table 5. Respondents' opinions about low prices when online shopping

\begin{tabular}{llc}
\hline Agree & Ordinary/Normal & Not Agree \\
\hline 18 orang & 15 orang & - \\
\hline
\end{tabular}

Price is one of the determinants of consumers in purchasing decisions, in this case in table 5 18 people $(18 / 33 \mathrm{X} 100 \%=55 \%)$ respondents agreed and 15 people $(15 / 33 \mathrm{X} 100 \%=45 \%)$ stated normal.

Table 6. Respondents' opinions about online sales sites

\begin{tabular}{|c|c|}
\hline Trustworthy sites & Number of respondents \\
\hline $\begin{array}{ll}- & \text { There is a system }\end{array}$ & 8 \\
\hline - $\quad$ Provided a security guarantee by the & \\
\hline online shopping site & \\
\hline - $\quad$ Many positive responses from other & \\
\hline buyers & \\
\hline The goods sold are genuine & \\
\hline There are reviews \& testimonials & 11 \\
\hline There is a warranty from the application & 2 \\
\hline Can not be trusted & \\
\hline Damaged goods & 1 \\
\hline There is fraud & 2 \\
\hline Not always & \\
\hline $\begin{array}{l}\text { That depends on our selection of the } \\
\text { verified online shopping site (guaranteed safe) }\end{array}$ & 8 \\
\hline
\end{tabular}

Table 6, Consumers will choose shopping on websites that he believes can be trusted. 21 respondents, $21 / 32 \mathrm{X} 100 \%=66 \%$ said they believed, the reason was because there was a system, there was a guarantee of security by the online shopping site, seeing reviews / positive responses from other buyers, original products sold, and there was a guarantee from the application (the website ). The level of trust is needed because consumers cannot see the product/service directly, only images. 
Table 7. Respondents' opinions regarding the accuracy (quality and quantity) of products/ services purchased online with display on the internet

\begin{tabular}{ccc}
\hline Exactly the same & A little different & $\begin{array}{l}\text { Completely different between } \\
\text { the image and the tangible } \\
\text { form of the product/service }\end{array}$ \\
\hline 9 orang & 25 & - \\
\hline
\end{tabular}

In this table 7 the respondents' opinions regarding the accuracy (quality and quantity) of products/services purchased online with display on the internet are 25 respondent: 25 / $34 \mathrm{X} 100 \%=74 \%$ say slightly different and those who say there are exactly 9 respondent: 9 / $34 \mathrm{X} 100 \%=26 \%$. Basically consumers judge products by their quality which then leads to consumer confidence in these products and if that trust can be maintained there will be consumer loyalty. Loyal consumers are consumers who are satisfied with the product/service, [10] as there is in theory from Kotler's book.

Table 8. Respondents felt based on background/reasons for shopping online:

\begin{tabular}{cccccccc}
\hline Ordinal & $\begin{array}{c}\text { Product/services } \\
\text { A }\end{array}$ & Price & Distribution & Promotion & $\begin{array}{c}\text { Physical } \\
\text { evidence }\end{array}$ & People & Process \\
& & B & C & D & & F & G \\
\hline 1 & 18 & 12 & 1 & - & - & - & - \\
2 & 5 & 15 & 4 & 6 & 1 & 1 & 1 \\
3 & 3 & 3 & 6 & 11 & 3 & 6 & 2 \\
4 & 4 & 4 & 3 & 1 & 2 & 8 & 9 \\
\hline
\end{tabular}

Based on the marketing mix of $7 \mathrm{P}$ in table 8 , product, price, distribution, promotion, physical facilities, people and processes. The following is the order that respondents felt based on their background/reason for shopping online. The product became the first place with $60 \%$ of respondents choosing. The second order is Price, $50 \%$ of respondents choose as a background for online shopping, promotion factor becomes the third background $36 \%$ of respondents choose online shopping. This proves that in online shopping respondents as millennial generation say the products/services offered are primary when deciding online shopping.

\section{Conclusion}

Through research, it can be concluded that the phenomenon of online shopping in the millennial generation are:

1. Millennials who love online shopping with practical online shopping reasons, cheaper prices, complete product variants/types, products purchased according to expectations, save time, quickly reach consumers and online shopping is also easy to do. 
2. The types of products purchased online by the millennial generation are clothing, secondmost are beauty products, then third, electronics. Types of Services purchased online are transportation tickets. Their opinions on the prices of these products and services are affordable.

3. The background of the millennial generation when deciding online shopping is to look at the product, which is the first order of $7 \mathrm{P} /$ seven marketing mix, the second price, the third promotion factors followed by distribution, process, people and physical facilities. This means that millennials pay attention to quality when shopping online.

\section{Acknowledgement}

1. Ibu Connie Rasilim, S.S., B.Ed., M.Pd., Dean of FIP Universitas Pelita Harapan who gave inputs on the millenial generation

2. LPPM Universitas Pelita Harapan who has funded the publication of InCoGITE

\section{References}

[1] Kotler P, Armstrong G, Ang SH, Leong SM, Tan CT, Hon-Ming OY. PRINCIPLES OF MARKETING AN ASIAN PERSPECTIVE. Jurong: Pearson Education South Asia Pte Ltd; 2011.

[2] KD H. Hadapi Era Digital, Jokowi: Pemerintah Perlu Terapkan DILAN [Internet]. Kontan.co.id. [cited 2019 Jul 25]. Available from: https://nasional.kontan.co.id/news/hadapi-era-digital-jokowipemerintah-perlu-terapkan-dilan

[3] Ryan D. Understanding Digital Marketing: Marketing Strategies for Engaging the Digital Generation [Internet]. Fourth edi. Philadelphia: Print/E-mail/Save 40 Pages Restricted Copy/Paste; 2016. Available from: http://ezproxy.library.uph.edu:2076/ehost/ebookviewer/ebook/bmxlYmtfXzE0MDYwNzBfX0FO0?si d=cbedd056-483e-4010-8bf4-10ca5de7c85a@ pdc-v-sessmgr01\&vid=1\&format=EB\&rid=1

[4] Kotler P, KartaJaya H, Setiawan I. Marketing 4.0 Moving from Traditional to Digital. New Jersey: John Wiley \& Sons, Inc; 2017.

[5] Elliott G, RUNDLE-THIELE S, Waller D. Marketing. Third. Milton, Australia: John Wiley \& Sons; 2014.

[6] Sangadji EM, Sopiah. Perilaku Konsumen Pendekatan Praktis disertai Himpunan Jurnal Penelitian. WK N, editor. Yogyakarta: Penerbit ANDI; 2013.

[7] Supranto J, Limakrisna N. PERILAKU KONSUMEN DAN STRATEGI PEMASARAN Untuk Memenangkan Persaingan Bisnis. Pertama. Jakarta: Penerbit Mitra Wacana Media; 2007.

[8] Iskandar. Metodologi Penelitian Pendidikan dan Sosial. Yamin HM, editor. Ciputat: Referensi; 2013.

[9] Buchari A. Manajemen Pemasaran dan Pemasaran Jasa. Revisi. Bandung: CV AlFABETA; 2005.

[10] Kotler P, Armstrong G. Prinsip-prinsip pemasaran. Jakarta: [Internet]. 2008 [cited 2016 Aug 8]; Available from: http://kundang.weblog.esaunggul.ac.id/wpcontent/uploads/sites/99/2016/03/MATERI-4-KUL-ONLINE2016.pdf 